\title{
Analysis correlation of the Implementation Framework COBIT 5, ITIL V3 and ISO 27001 for ISO 10002 Customer satisfaction
}

\author{
Marastika Wicaksono aji bawono ${ }^{1}$, Mohammad Amin Soetomo ${ }^{2,}$ Thata Apriatin ${ }^{3,}$ \\ ${ }^{1}$ Master of Information Technology, Swiss German University, Tangerang 15143, Indonesia
}

\section{Article Information}

Received: 28 November 2020

Accepted: 28 November 2020

Published: 6 December 2020

DOI:

\section{Corresponding Author:}

Marastika Wicaksono Aji Bawono, Mohammad Amin Soetomo,and Thata Apriatin

Email:

marastika.bawono@student.sgu.ac.id mohammad.soetomo@sgu.ac.id thata.apriatin@student.sgu.ac.id

\section{ISSN}

\begin{abstract}
Abstract - This study aims to determine and provide information about the corellation of COBIT 5, ITILV3 , and ISO 27001 for customer satisfaction. This study uses a causal associative method with a quantitative approach. The population of this research is all customers of company Quota Broadband Internet. The sampling technique in this research is probability sampling technique through simple random sampling. The research sample was 135 customers. The results showed that there was an corellation of COBIT 5 (6.Customer-oriented service culture), ITIL V3 (Service Operation 4.2 Incident management), and ISO 27001 (A.16 Information security incident management) for 10002 (3.4 customer satisfaction).. The biggest influence is COBIT 5 on ISO 27001 with a T statistic of 6,960 and a $P$ value of 0,000 .
\end{abstract}

Keywords - COBIT 5, ITILV3, ISO 27001, ISO 10002, Customer Satisfaction

\section{Introduction}

This study explores the analysis of the link between the introduction of a variety of frameworks to increase customer satisfaction in the business. Within this business, the COBIT 5 framework is used as a governance framework that focuses on the scope of 6 . Customer-oriented service culture and RACI work position framework based on job descriptions and has introduced the ITIL V3 framework that focuses on service operation 4.2 Incident management using the engine management service application service desk.managed problem with customer service center for internet service complaints handling.[7] to reduce corporate cyber crimes using the ISO 27001 information system security, which focuses on the scope of A. 16 Information security incident management for information security.[9] Both frameworks seek to enhance 3.4 customer satisfaction in compliance with ISO 10002 framework requirements. The purpose of this research is therefore to examine the combination of parameter tools from different frameworks that have been applied in order to obtain best practice parameters and tools that can increase customer satisfaction .[16] The use of information technology poses a major risk to information systems and in particular, to critical resources due to its own nature[1]

Information security must also be carefully maintained and controlled. Information security is the protection of information from various threats to ensure continuity of operations, minimize business risks and maximize investment returns and business opportunities [2].

By using an international standard framework to guarantee $100 \%$ security protection, a set of benchmarks or guidelines is required to help maintain a sufficient level of protection for the corellational use of resources. 
Customer satisfaction is one of the main outcomes measured. Customer satisfaction is the result of the goods and services of the business are equal to or greater than the requirements of the customer[3]. The degree of customer satisfaction can be calculated on the basis of five key factors to be regarded by a company, namely a) the product, customers are satisfied if the goods are reliable and durable. (b) Quality of service, customers are satisfied if the services provided are provided as planned, especially in the service sector.(c) Empathy emotionally, pride of consumers is preserved because of brand name and swift response is fulfilled when concerns and problems are identified. (d) Price, goods of the same quality but of a comparatively lower price would offer greater value to customers.[23] (e) Fees, customers do not have to pay installation or repair costs if there is an internet service disruption because it is included in the terms of the contract.

\section{Literature Review}

COBIT 5 offers a mechanism to ensure that the information technology used by businesses is in line with business needs. In addition, COBIT 5 is managed appropriately ensuring responsible managed appropriately use of information technology resources and ensuring information technology risks, so that information technology can support business properly and be able to maximize benefits provided. [5]. ITIL V3 is a compilation of best practices for handling IT services. ITIL V3 helps businesses to realize the value of their IT services to internal and external stakeholders. The ITIL safety management approach describes the establishment of formal protection in a management organization[7]. A variety of good practices, such as ITIL V3 and ISO/IEC 27001, can be used as a basis for developing a sound information security process[8].

The ISO/IEC 27001 standard specifies the requirements for the proper design and implementation of the Information security management system (ISMS) within the organization to ensure that appropriate and proportionate controls are chosen to protect the information assets and to provide trust to interested parties[9].The integration of best-practice security practices such as ISO/IEC 27001 into best-practice service management processes such as ITIL V3 helps organizations to mitigate overall costs in order to maintain an acceptable level of security, manage risk effectively and reduce overall risk[10].The ISO/IEC 27001 standard ISO/IEC 27001 is based on the Code of Practice released by the United Kingdom Department of Trade and Industry in 1989, which slowly became BS7799. ISO/IEC 27001 is a set of standards that can be used by organizations to create, deploy and maintain the Information Security Management System (ISMS)[2]. Based on a number of journals and the above definition, the novelty of research conducted by ITIL V3 researchers, Quota Broadband Internet, and customer satisfaction. The author has the initiative to analyze the basic concepts for the application of COBIT 5, ITIL V3 and ISO 27001 on 10002 customer satisfaction.

Al Faruq et al. said, IT organizations have adopted standards, i.e. ISO 2000 (Service management), ISO 9001 (Quality management system) and ISO 27001 (Quality management system) for information security have gained additional benefits such as customer satisfaction and confidence .[16]

In addition, Sahibudin et.al confirms that the combination of ITIL V3, Cobit and ISO/IEC 27002 is of benefit to the organization's objectives.[16] ITIL V3 will define procedures, plans and processes, COBIT 5 for metrics, benchmarks and audits, and ISO/IEC 27002 for resolving safety concerns relevant to risk reduction. [9]. In carrying out our research mapping COBIT 5 scope 6 . Customer-oriented service culture applicable to ISO/IEC 27001: 2013 scope A.16 Information security incident management distance analysis ITIL V3 scope (Service operation 4.2 incident management) to figure 1.ITIL V3 .[4] 


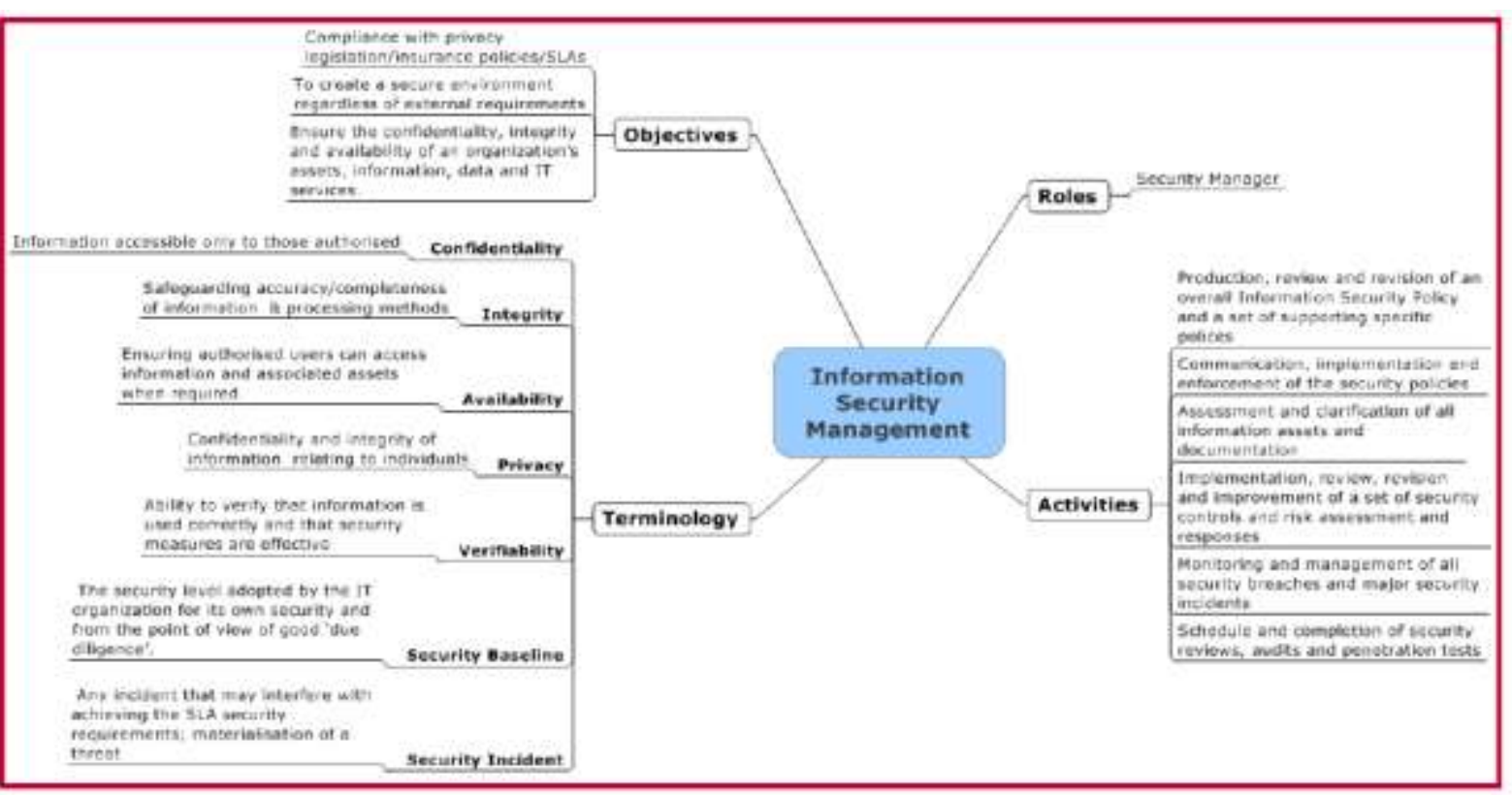

Figure 1. ITIL V3 Information security management

In carrying out our research mapping, we focus on the integration of the COBIT 5 link-up space structure (6. Customer-oriented service culture) as information technology governance in the management of RACI organizational structures and the introduction of the ITIL V3 framework-corellation domain-based activities for IT service management [6].

In the handling of internet disruptions within the framework of Service Operation 4.2 Incident management which has an impact on the achievement of international standards in ISO 27001 companies within the scope of A.16 Incident management to improve 3.4 Customer satisfaction with the implementation of ISO 10002. There are elements of innovation or results of this study in this study that differentiate the following methods from previous research:

Table 1. The difference between this study and other papers

\begin{tabular}{|c|c|c|c|c|}
\hline No & Paper Tittle & Methods & $\begin{array}{c}\text { Contribution } \\
\text { novelty }\end{array}$ & Weaknesses \\
\hline 1 & $\begin{array}{l}\text { Marastika wicaksono aji } \\
\text { bawono,Mohammad } \\
\text { Amin Soetomo, Thata } \\
\text { Apriatin, } \\
\text { "Analysis The } \\
\text { corellation of the } \\
\text { Implementation of Cobit } \\
\text { 5, ITILV3 and ISO } \\
27001 \text { for ISO } 10002 \\
\text { Customer satisfaction" }\end{array}$ & $\begin{array}{l}\text { (Structual equal } \\
\text { modeling) } \\
\text { SEM PLS 3.2.4 } \\
\text { Professional. } \\
\text { Quantitative } \\
\text { Research } \\
\text { Path analysis }\end{array}$ & $\begin{array}{l}\quad \text { determine the } \\
\text { existence of a causal } \\
\text { corellation due to } \\
\text { implementing } \\
\text { various best practice } \\
\text { frameworks in the } \\
\text { company }\end{array}$ & $\begin{array}{l}\text { This data processing } \\
\text { application SEM PLS } \\
\text { will only get maximum } \\
\text { results if we use a small } \\
\text { data size, but it is not } \\
\text { very suitable for research } \\
\text { with large samples. } \\
\text { Requires interviews with } \\
5 \text { in-depth respondents } \\
\text { using random sampling } \\
\text { to increase data accuracy } \\
\text { that the results of the } \\
\text { validity of the } \\
\text { quantitative research } \\
\text { method have answered } \\
\text { all hypotheses }\end{array}$ \\
\hline
\end{tabular}




\begin{tabular}{|c|c|c|c|c|}
\hline 2 & $\begin{array}{l}\text { B. Al Faruq, H. R. } \\
\text { Herlianto, S. H. } \\
\text { Simbolon, D. N. Utama, } \\
\text { and A. Wibowo, } \\
\text { "Integration of ITIL V3, } \\
\text { ISO } 20000 \text { \& iso } \\
\text { 27001:2013forit services } \\
\text { and security } \\
\text { management system," } \\
\text { Int. J. Adv. Trends } \\
\text { Comput. Sci. Eng., vol. } \\
\text { 9, no. 3, pp. 3514-3531, } \\
\text { 2020, doi: } \\
\text { 10.30534/ijatcse/2020/1 } \\
\text { 57932020 }\end{array}$ & $\begin{array}{l}\text { PDCA } \\
\text { (Plan,do,check,act) } \\
\text { Qualitative } \\
\text { Research }\end{array}$ & $\begin{array}{l}\text { Companies adopt } \\
\text { some framework } \\
\text { intention to meet } \\
\text { the international } \\
\text { standards and } \\
\text { certification will } \\
\text { get more benefits } \\
\text { such as improved } \\
\text { standards }\end{array}$ & $\begin{array}{l}\text { Research results depend } \\
\text { on the ability and } \\
\text { experience of the } \\
\text { researcher. } \\
\text { Possible changes in the } \\
\text { behavior of the object of } \\
\text { study } \\
\text { Non-standard research } \\
\text { procedures.r. }\end{array}$ \\
\hline
\end{tabular}

\section{Method}

For a quantitative approach, the study uses the causal associative method. Test was conducted on customers of the Company Quota Broadband Internet This location was chosen on the basis that the issue presented in the study included the company Quota Broadband Internet Period. This research was conducted between July and December 2020. Both customers of the Quota Broadband Internet Service were part of the population of this report. The sampling method used in this analysis is the technique of random sampling by simple random sampling. The research sample consisted of 135 external customers. The data collection technique shall be in the form of a questionnaire given to the customers of the Quota Broadband Internet Company. The questionnaire was based on a variety of observations and synthesized hypotheses, the questionnaire was based on a range of observations and synthesized hypotheses, conceptual principles, operational descriptions and a network of testing instruments. Study data analysis using SEM PLS version 3.2.4 Technical application tools.

\section{Results and Discussion}

Outer Models The results of research using SEM PLS version 3.2.4 Professional are shown in Figure 2 and 3 below:

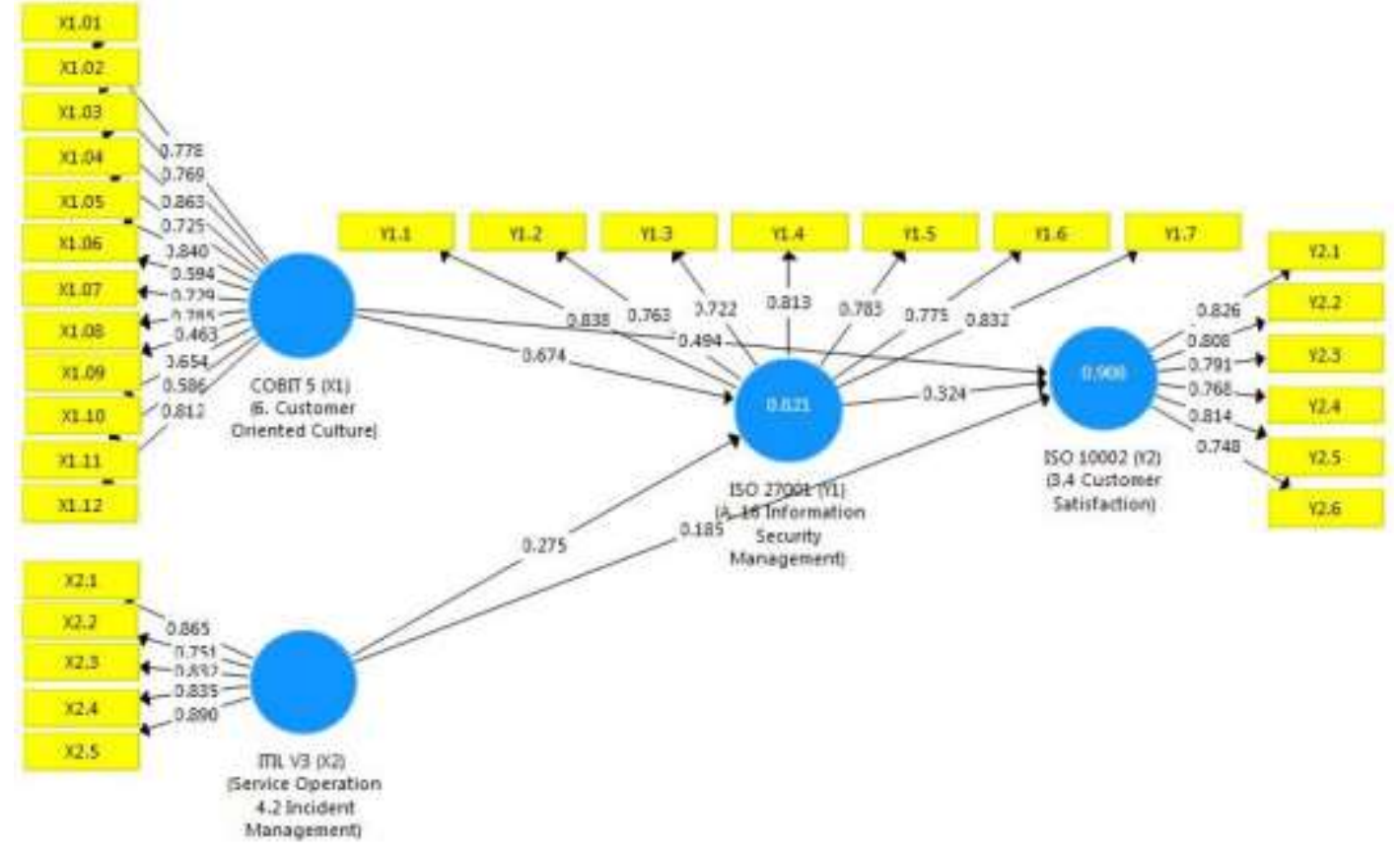

Figure 2. Initial outer models 
In the initial outer model, classification is used to exclude data anomalies outside the structural and below the uniform figure that are not appropriate for testing in the study Outer loadings value shows the relationship between the indicator and its architecture [12].

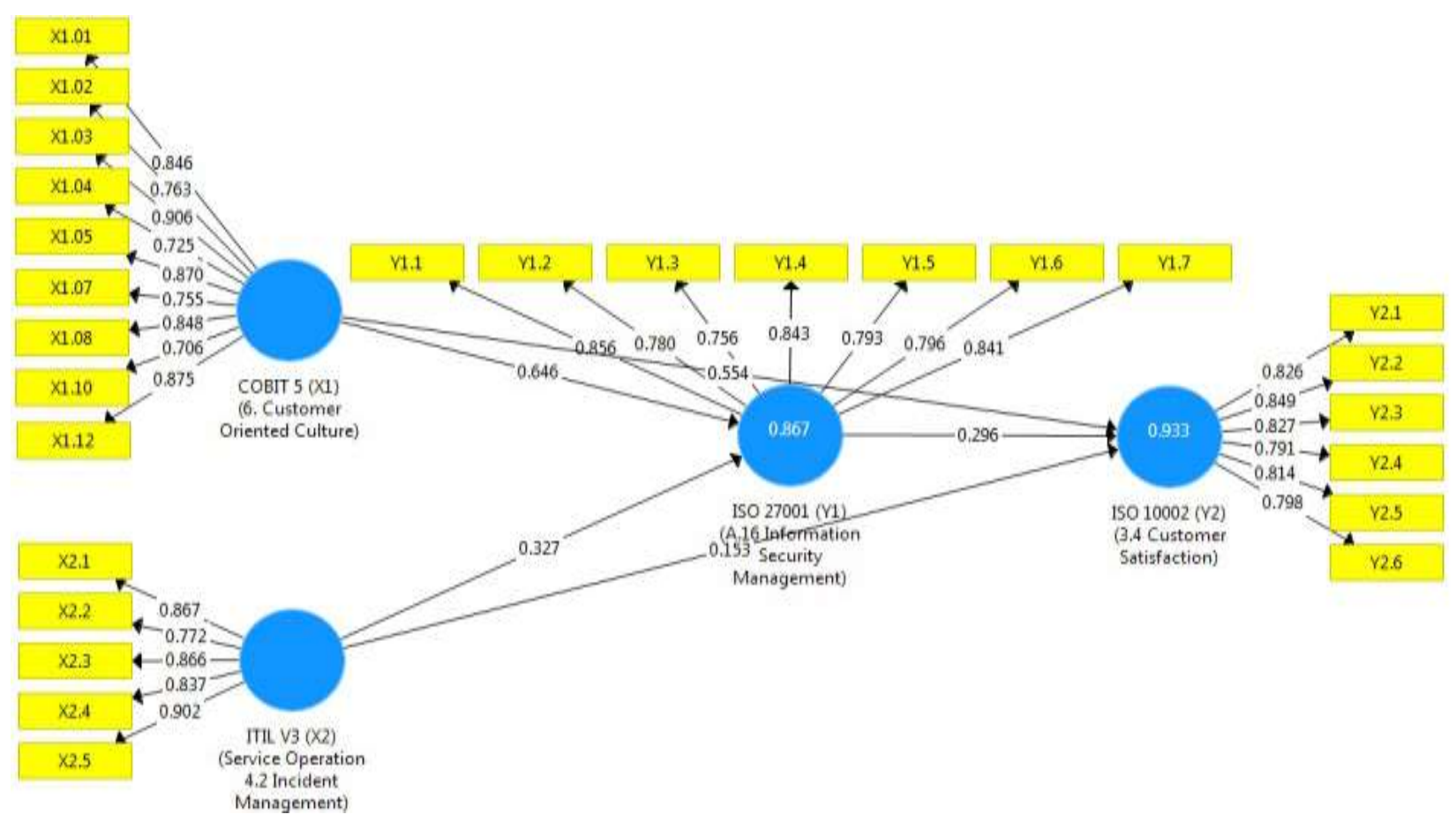

Figure 3. Final outer models

The low external load value indicator implies that the indicator does not function on the measurement model.[5] For each independent and dependent variable, the effects of the following initial external model are shown in the statement instrument:

Table 2. Framework statement instrument

\begin{tabular}{|l|l|l|l|}
\hline $\begin{array}{l}\text { Statement instrument } \\
\text { COBIT 5 (X1) }\end{array}$ & $\begin{array}{l}\text { Statement } \\
\text { instrument } \\
\text { ITIL V3 (X2) }\end{array}$ & $\begin{array}{l}\text { Statement instrument } \\
\text { ISO 27001 (Y1) }\end{array}$ & $\begin{array}{l}\text { Statement instrument } \\
\text { ISO 10002 (Y2) }\end{array}$ \\
\hline $\begin{array}{l}\text { Scope 6.Customer-oriented } \\
\text { service culture }\end{array}$ & $\begin{array}{l}\text { Scope Service } \\
\text { operation 4.2 } \\
\text { incident } \\
\text { management }\end{array}$ & $\begin{array}{l}\text { Scope A.16 Information security } \\
\text { incident management }\end{array}$ & $\begin{array}{l}\text { Scope 3.4 Customer } \\
\text { satisfaction }\end{array}$ \\
\hline $\begin{array}{l}\text { X1.01.The Company is } \\
\text { already aligning IT and } \\
\text { business strategy }\end{array}$ & $\begin{array}{l}\text { X2.1.The Company } \\
\text { ensures that } \\
\text { standard methods } \\
\text { and procedures are } \\
\text { used for efficient } \\
\text { and fast response, } \\
\text { analysis,documentat } \\
\text { ion, and } \\
\text { sustainability } \\
\text { management and } \\
\text { incident reporting }\end{array}$ & $\begin{array}{l}\text { Y1.1.The Company control over } \\
\text { responsibilities and management } \\
\text { procedures must be established to } \\
\text { ensure prompt, corellationive and } \\
\text { regular information responses } \\
\text { security incident. }\end{array}$ & $\begin{array}{l}\text { Y2.1.Customers have a } \\
\text { perception about the extent to } \\
\text { which customer expectations } \\
\text { have been met in the internet } \\
\text { service received }\end{array}$ \\
\hline
\end{tabular}




\begin{tabular}{|c|c|c|c|}
\hline $\begin{array}{l}\text { X1.02.The Company } \\
\text { conducts IT service delivery } \\
\text { in line with the business } \\
\text { requirements }\end{array}$ & $\begin{array}{l}\text { X2.2.The Company } \\
\text { increases visibility } \\
\text { and communication } \\
\text { incident to business } \\
\text { and IT support staff }\end{array}$ & $\begin{array}{l}\text { Y1.2. The Company control of the } \\
\text { will Information security incidents } \\
\text { should be reported through the } \\
\text { appropriate channel management as } \\
\text { quickly as possible. }\end{array}$ & $\begin{array}{l}\text { Y2.2 Customer satisfaction has } \\
\text { been fulfilled according to } \\
\text { customer expectations contained } \\
\text { in the performance report } \\
\text { contract of the service leveel } \\
\text { guarantee and service leve } \\
\text { agreement }\end{array}$ \\
\hline $\begin{array}{l}\text { X1.03.Customers Realize the } \\
\text { benefits of IT support } \\
\text { investment portfolio and } \\
\text { services }\end{array}$ & $\begin{array}{l}\text { X2.3 The Company } \\
\text { have a business } \\
\text { perception of IT } \\
\text { through use from a } \\
\text { professional } \\
\text { approach to } \\
\text { finishing quickly } \\
\text { and communicate } \\
\text { incidents as they } \\
\text { occur }\end{array}$ & $\begin{array}{l}\text { Y1.3. The Company controls } \\
\text { employees who use organizational } \\
\text { information systems and services } \\
\text { must record and report each } \\
\text { observe or suspect information } \\
\text { security weaknesses in the system } \\
\text { or service. }\end{array}$ & $\begin{array}{l}\text { Y2.3 The customer knows if } \\
\text { there is maintenance of internet } \\
\text { which can cause down time that } \\
\text { has been calculated in the MTTR } \\
\text { (Mean time to repair) for service } \\
\text { interruptions }\end{array}$ \\
\hline $\begin{array}{l}\text { X1.04.The Company knows } \\
\text { the importance of using the } \\
\text { application, adequate } \\
\text { information and technology } \\
\text { solutions }\end{array}$ & $\begin{array}{l}\text { X2.4 The Company } \\
\text { synchronize incident } \\
\text { management } \\
\text { activities and } \\
\text { priority with } \\
\text { business }\end{array}$ & $\begin{array}{l}\text { Y1.4.The Company control over } \\
\text { Information security events have to } \\
\text { be assessed and it must bedecide } \\
\text { whether they will be classified as } \\
\text { an information security incident. }\end{array}$ & $\begin{array}{l}\text { Y2.4 The company and the } \\
\text { customer carry out the } \\
\text { provisions of the SLA (Service } \\
\text { level agreement) and SLG } \\
\text { (Service level guarantee) } \\
\text { requirements which are expected } \\
\text { to be } 95 \% \text { according to what has } \\
\text { been agreed with the customer in } \\
\text { order to meet a high level of } \\
\text { customer satisfaction. }\end{array}$ \\
\hline $\begin{array}{l}\text { X1.05.The Company has IT } \\
\text { agility solutions in the face of } \\
\text { business competition }\end{array}$ & $\begin{array}{l}\text { X2.5 The Company } \\
\text { Maintain user } \\
\text { satisfaction with } \\
\text { the quality of IT } \\
\text { services. }\end{array}$ & $\begin{array}{l}\text { Y1.5 The company controls } \\
\text { Information security incidents } \\
\text { should be responded to accordingly } \\
\text { with a documented procedure. }\end{array}$ & $\begin{array}{l}\text { Y2.5 The company provides } \\
\text { complaints via the care center } \\
\text { for customers so that they can } \\
\text { send complaints about } \\
\text { interruption of internet services } \\
\text { so that the handling of } \\
\text { complaints is carried out openly } \\
\text { and responsively }\end{array}$ \\
\hline $\begin{array}{l}\text { X1.06.The Company } \\
\text { optimizes the empowerment } \\
\text { of human resources for } \\
\text { business support processes by } \\
\text { integrating applications and } \\
\text { technology into business } \\
\text { processes }\end{array}$ & & $\begin{array}{l}\text { Y1.6 The company controls the } \\
\text { knowledge and information data } \\
\text { obtained to analyze and resolve } \\
\text { information security incidents } \\
\text { should be used to reduce the } \\
\text { likelihood or impactuture incidents. }\end{array}$ & $\begin{array}{l}\text { Y2.6 The company improves the } \\
\text { competence of employees in } \\
\text { each work unit in resolving } \\
\text { complaints consistently, } \\
\text { systematically, and responsive } \\
\text { way }\end{array}$ \\
\hline $\begin{array}{l}\text { X1.07.The Company submits } \\
\text { the RJPP program (the } \\
\text { company's long-term plan) } \\
\text { benefits, on time, within } \\
\text { budget, and in meetings } \\
\text { requirements and quality } \\
\text { standards }\end{array}$ & & $\begin{array}{l}\text { Y1.7 The company establishes and } \\
\text { implements procedures for } \\
\text { identification, gathering, obtaining } \\
\text { and preserving information,that can } \\
\text { be evidence. }\end{array}$ & \\
\hline
\end{tabular}




\begin{tabular}{|l|l|l|l|}
\hline $\begin{array}{l}\text { X1.08.The Company has } \\
\text { human resources who are } \\
\text { competent and motivated } \\
\text { IT personnel to support } \\
\text { business processes }\end{array}$ & & & \\
\hline $\begin{array}{l}\text { X1.9 The company maintains } \\
\text { an effective internal control } \\
\text { system }\end{array}$ & & & \\
\hline $\begin{array}{l}\text { X1.10.Business partners } \\
\text { control the information chain } \\
\text { between them? }\end{array}$ & & & \\
\hline $\begin{array}{l}\text { X1.11.The Company } \\
\text { provides Knowledge, } \\
\text { expertise and initiativefor } \\
\text { Employees to business } \\
\text { innovation }\end{array}$ & & & \\
\hline $\begin{array}{l}\text { X1.12.The Company has an } \\
\text { internal policy on IT services }\end{array}$ & & & \\
\end{tabular}

Table 3 Outer Loadings

\begin{tabular}{|c|c|c|c|c|}
\hline \multirow[b]{2}{*}{ Indicator } & \multicolumn{4}{|c|}{ Latent Variable } \\
\hline & $\begin{array}{l}\text { COBIT } 5 \text { (X1) } \\
\text { 6.Customer- } \\
\text { oriented service } \\
\text { culture }\end{array}$ & $\begin{array}{l}\text { ITIL V3 (X2) } \\
\text { Service } \\
\text { operation } \\
4.2 \text { incident } \\
\text { management }\end{array}$ & $\begin{array}{l}\text { ISO } 27001 \text { (Y1) } \\
\text { A.16 Information } \\
\text { security incident } \\
\text { management }\end{array}$ & $\begin{array}{l}\text { ISO } 10002 \text { (Y2) } \\
\text { 3.4 Customer } \\
\text { satisfaction }\end{array}$ \\
\hline X1.01 & 0.846 & & & \\
\hline $\mathrm{X} 1.02$ & 0.763 & & & \\
\hline $\mathrm{X} 1.03$ & 0.906 & & & \\
\hline $\mathrm{X} 1.04$ & 0.725 & & & \\
\hline $\mathrm{X} 1.05$ & 0.87 & & & \\
\hline $\mathrm{X} 1.07$ & 0.755 & & & \\
\hline $\mathrm{X} 1.08$ & 0.848 & & & \\
\hline $\mathrm{X} 1.10$ & 0.706 & & & \\
\hline $\mathrm{X} 1.12$ & 0.875 & & & \\
\hline $\mathrm{X} 2.1$ & & 0.867 & & \\
\hline $\mathrm{X} 2.2$ & & 0.772 & & \\
\hline
\end{tabular}




\begin{tabular}{|l|l|l|l|l|}
\hline X2.3 & & 0.866 & & \\
\hline X2.4 & & 0.837 & & \\
\hline X2.5 & & 0.902 & & \\
\hline Y1.1 & & & 0.856 & \\
\hline Y1.2 & & & 0.780 & \\
\hline Y1.3 & & & 0.756 & \\
\hline Y1.4 & & & 0.843 & \\
\hline Y1.5 & & & 0.793 & \\
\hline Y1.6 & & & 0.796 & \\
\hline Y1.7 & & & 0.841 & 0.826 \\
\hline Y2.1 & & & & 0.849 \\
\hline Y2.2 & & & & 0.827 \\
\hline Y2.3 & & & & 0.791 \\
\hline Y2.4 & & & & 0.814 \\
\hline Y2.5 & & & & \\
\hline Y2.6 & & & & \\
\hline
\end{tabular}

The analysis uses a standard external load weight of 0.7. The findings indicate that all external load values are $>0.7$ for each predictor.[15] In most sources, a factor weight of 0.70 or more is believed to have been fairly well validated to describe latent constructions. Higher external load indicators have a higher contribution to describe latent construction. On the other hand, indicators with low external loads have a poor contribution to defining their latent (valid) construction. The AVE value must be higher $(>0.5)$. [7]

Table 4 Average variance extracted (AVE)

\begin{tabular}{|l|l|}
\hline Latent Variable & $\begin{array}{l}\text { Average Variance } \\
\text { Extracted } \\
\text { (AVE) }\end{array}$ \\
\hline $\begin{array}{l}\text { COBIT 5 (X1) } \\
\text { (6. Customer-oriented service culture) }\end{array}$ & 0.662 \\
\hline $\begin{array}{l}\text { ITIL V3 (X2) } \\
\text { (Service operation 4.2 Incident management) }\end{array}$ & 0.722 \\
\hline $\begin{array}{l}\text { ISO 27001 (Y1) } \\
\text { (A.16 Information security incident management) }\end{array}$ & 0.656 \\
\hline $\begin{array}{l}\text { ISO 10002 (Y2) } \\
\text { (3.4 customer satisfaction) }\end{array}$ & 0.668 \\
\hline
\end{tabular}


Based on the above table, it is shown that the value of AVE COBIT 5 (X1) (6.Customer-oriented service culture value is 0.662. AVE ITIL V3 (X2) (Service operation 4.2 incident management) is 0.722. AVE ISO 27001 (Y1) A.16 incident management value of 0.656. ISO 10002 (Y2) AVE price (3.4 Customer satisfaction is 0.668 ). This is the result of the Convergence Test Validity Study of the Average Variance Extract (AVE) value > 0.5. [22]

Discriminant validity refers to the degree of variance between the non-calculated characteristics of the measurement system and the theoretical principles of the variable. Discriminant Validity of the reflexive measurement model can be determined on the basis of the Fornell Larcker criterion value and the crossloading value of the manifest variable for each latent variable. The criterion for the value of the Fornell Larcker criterion must be greater than the AVE value of each latent variable, the criterion for the Fornell Larcker criterion must be greater than the AVE value of each latent variable, which means that the degree of mismatch between attributes which should not be calculated by the measuring instrument is small, so that the discriminant value is included in the criterion.

Table 5 Fornell larcker criterion

\begin{tabular}{|l|l|l|l|l|}
\hline Latent Variable & $\begin{array}{l}\text { COBIT 5 (X1) } \\
\text { 6.Customer- } \\
\text { oriented service } \\
\text { culture }\end{array}$ & $\begin{array}{l}\text { ISO 27001 (Y1) } \\
\text { A.16 } \\
\text { Information } \\
\text { security } \\
\text { incident } \\
\text { management }\end{array}$ & $\begin{array}{l}\text { ITIL V3 (X2) } \\
\text { Service operation } \\
\text { 4.2 incident } \\
\text { management }\end{array}$ & $\begin{array}{l}\text { ISO 10002 (Y2) } \\
\text { satisfaction }\end{array}$ \\
\hline $\begin{array}{l}\text { COBIT 5 (X1) } \\
\text { 6.Customer- } \\
\text { oriented service } \\
\text { culture }\end{array}$ & 0.814 & 0.810 & 0.850 & \\
\hline $\begin{array}{l}\text { ISO 27001 (Y1) } \\
\text { A.16 Information } \\
\text { security incident } \\
\text { management }\end{array}$ & 0.911 & 0.851 & 0.855 & \\
\hline $\begin{array}{l}\text { ITIL V3 (X2) } \\
\text { Service Operation } \\
\text { 4.2 Incident } \\
\text { management }\end{array}$ & 0.811 & 0.932 & & \\
\hline $\begin{array}{l}\text { ISO 10002 (Y2) } \\
\text { 3.4 customer } \\
\text { satisfaction }\end{array}$ & 0.949 & & & \\
\hline
\end{tabular}

The table above shows that the value of the latent variable association between COBIT 5 (X1) (6.Customeroriented service culture) is 0.814 higher than the AVE value of 0.662. ITIL V3 (X2) (Service operation 4.2 incident management) of 0.850 is higher than the AVE of 0.722. The value of 0.81 ISO 27001 (Y1) is greater than the value of 0.656 AVE. ISO 10002 (Y2) 3.4 The customer satisfaction value of 0.818 is higher than the AVE value of 0668 (ISO 10002 3.4). The above table shows that the value of the latent variable relation between Cobit 5 (X1) (6.Customer-oriented service culture) is 0.814 higher than the AVE value of 0.662 . ITIL V3 (X2) (Service operation 4.2 incident management) is 0.850 higher than the AVE of 0.722.The value of 0.81 ISO 27001 (Y1) is greater than the value of 0.656 AVE. (Y2) 0.818 is greater than the value of 0.668 ISO 10002 (Y2) (3.4 customer satisfaction). Criteria for the importance of cross-loading, that is, if the value 
of the correlation between the latent variable and one of its indicators (manifest variable) is greater than the value of the correlation with other latent variables, then the latent variable may be said to predict the indicator better than other latent variables [15].

Table 6 Cross Loadings

\begin{tabular}{|c|c|c|c|c|}
\hline \multirow[b]{2}{*}{ Indikator } & \multicolumn{4}{|c|}{ Latent Variable } \\
\hline & $\begin{array}{l}\text { COBIT } 5 \text { (X1) } \\
\begin{array}{l}\text { 6.Customer- } \\
\text { oriented service } \\
\text { culture }\end{array}\end{array}$ & $\begin{array}{l}\text { ITIL V3 (X2) } \\
\text { Service operation } \\
4.2 \text { oncident } \\
\text { management }\end{array}$ & $\begin{array}{l}\text { ISO } 27001 \text { (Y1) } \\
\text { A.16 Information } \\
\text { security incident } \\
\text { management }\end{array}$ & $\begin{array}{l}\text { ISO } 10002 \text { (Y2) } \\
\text { 3.4 Customer } \\
\text { satisfaction }\end{array}$ \\
\hline $\mathrm{X} 1.01$ & 0.846 & 0.620 & 0.728 & 0.794 \\
\hline $\mathrm{X} 1.02$ & 0.763 & 0.647 & 0.696 & 0.671 \\
\hline $\mathrm{X} 1.03$ & 0.906 & 0.639 & 0.777 & 0.843 \\
\hline $\mathrm{X} 1.04$ & 0.725 & 0.710 & 0.703 & 0.669 \\
\hline $\mathrm{X} 1.05$ & 0.870 & 0.553 & 0.721 & 0.808 \\
\hline $\mathrm{X} 1.07$ & 0.755 & 0.685 & 0.737 & 0.745 \\
\hline $\mathrm{X} 1.08$ & 0.848 & 0.577 & 0.756 & 0.796 \\
\hline $\mathrm{X} 1.10$ & 0.706 & 0.923 & 0.756 & 0.758 \\
\hline $\mathrm{X} 1.12$ & 0.875 & 0.598 & 0.784 & 0.831 \\
\hline $\mathrm{X} 2.1$ & 0.642 & 0.867 & 0.641 & 0.691 \\
\hline $\mathrm{X} 2.2$ & 0.680 & 0.772 & 0.742 & 0.729 \\
\hline $\mathrm{X} 2.3$ & 0.722 & 0.866 & 0.737 & 0.738 \\
\hline $\mathrm{X} 2.4$ & 0.712 & 0.837 & 0.702 & 0.748 \\
\hline $\mathrm{X} 2.5$ & 0.681 & 0.902 & 0.779 & 0.718 \\
\hline Y1.1 & 0.682 & 0.743 & 0.856 & 0.714 \\
\hline Y1.2 & 0.715 & 0.731 & 0.780 & 0.740 \\
\hline Y1.3 & 0.818 & 0.576 & 0.756 & 0.786 \\
\hline Y1.4 & 0.664 & 0.755 & 0.843 & 0.681 \\
\hline Y1.5 & 0.719 & 0.721 & 0.793 & 0.759 \\
\hline Y1.6 & 0.831 & 0.589 & 0.796 & 0.846 \\
\hline Y1.7 & 0.708 & 0.719 & 0.841 & 0.730 \\
\hline $\mathrm{Y} 2.1$ & 0.726 & 0.740 & 0.776 & 0.826 \\
\hline $\mathrm{Y} 2.2$ & 0.802 & 0.680 & 0.748 & 0.849 \\
\hline $\mathrm{Y} 2.3$ & 0.802 & 0.591 & 0.799 & 0.827 \\
\hline Y2.4 & 0.749 & 0.862 & 0.753 & 0.791 \\
\hline Y2.5 & 0.759 & 0.745 & 0.770 & 0.814 \\
\hline
\end{tabular}




\begin{tabular}{|l|l|l|l|l|}
\hline Y2.6 & 0.813 & 0.574 & 0.723 & 0.798 \\
\hline
\end{tabular}

Based on the above table, it can be seen that the COBIT 5 (X1) (6. Customer-oriented service culture) of the predictor is greater than the value of other latent variables. Latent values of ITIL V3 (X2) (Service operation 4.2 incident management), ISO 27001 (Y1) (A.16 Information security incident management) for ISO 10002 (Y2) (3.4 Customer satisfaction).

The reliability test consists of the composite reliability test and the Cronbach alpha test used to test the reliability value of the variable indicators. A variable can be declared to be met if it has a composite reliability and an alpha value of $>0.7$ Cronbach [8].

Table 7. Composite Reliability and Cronboach's Alfa

\begin{tabular}{|l|l|l|}
\hline Latent Variable & $\begin{array}{l}\text { Composite } \\
\text { Reliability }\end{array}$ & $\begin{array}{l}\text { Cronbach's } \\
\text { Alpha }\end{array}$ \\
\hline COBIT 5 (X1) 6. Customer-oriented service culture & 0.946 & 0.935 \\
\hline $\begin{array}{l}\text { ITIL V3 Service operation (X2) 4.2 Incident } \\
\text { management }\end{array}$ & 0.928 & 0.903 \\
\hline $\begin{array}{l}\text { ISO 27001 (Y1) } \\
\text { A.16 Information security incident management }\end{array}$ & 0.930 & 0.912 \\
\hline ISO 10002 (Y2) & & 0.901 \\
\hline
\end{tabular}

Based on the above table, it is shown that the composite reliability and the Cronbach alpha value of all study variables are >0.7.[5] These results indicate that each variable met the composite reliability and the Cronbach alpha, so that it can be concluded that all variables have a high degree of reliability.

Internal model evaluation is a structural model assessment consisting of the path coefficient, the Rsquare T-statistic (bootstropping), predictive significance, and model fit.[23] The path coefficient assessment is used to denote the intensity of the association or effect of the independent variable on the dependent variable.

Table 8. Path Coefficient

\begin{tabular}{|l|l|}
\hline Latent Variable & $\begin{array}{l}\text { Path } \\
\text { Coefficients }\end{array}$ \\
\hline COBIT 5 (X1) (Customer-oriented service culture) & 0.554 \\
\hline $\begin{array}{l}\text { ITIL V3 (X2) (Service Operation 4.2 Incident management) } \\
\text { to ISO 10002 (Y2) (3.4 customer satisfaction) }\end{array}$ & 0.153 \\
\hline $\begin{array}{l}\text { ISO 27001 (Y1) (A.16 Information security incident management) } \\
\text { to ISO 10002 (Y2) (3.4 customer satisfaction) }\end{array}$ & 0.296 \\
\hline $\begin{array}{l}\text { COBIT 5 (X1) (6.Customer-Oriented service cultutre) } \\
\text { to ISO 27001 (Y1) (A.16 Information security incident management) }\end{array}$ & 0.646 \\
\hline $\begin{array}{l}\text { ITIL V3 (X1) (Service Operation 4.2 Incident management) } \\
\text { to ISO 27001 (Y1) (A.16 Information security incident management) }\end{array}$ & 0.327 \\
\hline
\end{tabular}


Based on the above table, it is shown that the greatest coefficient of direction for the correlation of COBIT 5 (X1) (6. Customer-oriented service culture) on ISO 27001 (Y1) (A.16 information security incident management) is 0.646 .

The second big correlation is COBIT 5 (X1) (6. Customer-oriented service culture) for ISO 10002 (Y2) (3.4 Customer satisfaction) of 0.554. The third big effect is ITIL V3 (X2) (Service operation 4.2 incident management) on ISO 27001 (Y1) (A.16 Information security incident management) of 0.327. The fourth largest association is ISO 27001 (Y1) A.16 Information security incident management for ISO 10002 (Y2) (3.4 Customer satisfaction) of 0.296. The fifth highest effect is ITIL V3 (X2) (Service operation 4.2 incident management) for ISO 10002 (Y2) 3.4 customer satisfaction) of 0.153 .

Based on the interpretation of these correlations, it is shown that all variables in this model have a positive path coefficient. This shows that if the value of the path coefficient is greater on one independent variable on the dependent variable, the stronger the correlation on the dependent variable will be between the independent variables.

Coefficient determination (R-Square) is used to measure how much endogenous variables are affected by other variables. The R-Square result of 0.67 and above indicates that the endogenous latent variables in the structural model indicate the effect of the exogenous variables (which influence) on the endogenous variables (which are affected) in the good community. In the meantime if the result is $0.33-0.67$, it is in the medium-sized group and if the result is $0.19-0.33$, it is in the weak category[1].

On the basis of the data processing carried out using SEM PLS 3.2.4 Professional[12], the R Square value is obtained as follows:

Table 9. R-Square

\begin{tabular}{|l|l|l|}
\hline Latent Variable & R Square & R Square Adjusted \\
\hline $\begin{array}{l}\text { ISO 27001 (Y1) } \\
\text { (A.16 Information security incident } \\
\text { management) }\end{array}$ & 0.867 & 0.865 \\
\hline $\begin{array}{l}\text { ISO 10002 (Y2) } \\
\text { (3.4 customer satisfaction) }\end{array}$ & 0.933 & 0.931 \\
\hline
\end{tabular}

The R-Square value of the ISO 10002 3.4 Customer satisfaction (Y2) variable of 0.867 is included in the Positive category The acquisition of this value explains that the percentage of ISO 27001 (Y1) (A.16 Information security incident management) can be explained by COBIT 5 (X1) (6.Customer-oriented service culture) and ITIL V3 (X2) (Service operation 4.2 incident management) of $86.7 \%$. The remaining 13.3 per cent is influenced by variables other than COBIT 5 (6.Customer-oriented service culture) (X1) and ITIL V3 (Service operation 4.2 incident management) (X2).

The square value of the 0.933 vector (Y2) is included in the right group. The acquisition of this ISO 100023.4 customer satisfaction indicates that the percentage of Customer satisfaction (Y2) can be defined by COBIT 5 (6. Customer-oriented service culture) (X1), ITIL V3 (Service operation 4.2 incident management) (X2) and ISO 27001 (A.16 Information security incident management) (Y1) by $93.3 \%$.

The remaining $6.7 \%$ were affected by variables outside COBIT 5 (X1) (6. Customer-oriented service culture ITIL V3 (X2) (Service operation 4.2 incident management) and ISO 10002 (Y2) (3.4 Customer satisfaction). Hypothesis tests by looking at the value of T-Statistics and P-Values The study hypothesis may be described as agreed if the value of P-Values is $<0.05$ [12]. 
Table 10. T-Statistics and P-Values

\begin{tabular}{|c|c|c|}
\hline Latent Variable & T-Statistic & P-Values \\
\hline COBIT 5 (X1) & 5.091 & 0.000 \\
$\begin{array}{c}\text { (6.Customer-Oriented service culture ) } \\
\text { To ISO 10002 (Y2) (3.4 customer satisfaction) }\end{array}$ & 2.648 & 0.008 \\
\hline $\begin{array}{c}\text { ITIL V3 (X2)(Service Operation 4.2 Incident management) } \\
\text { to ISO 10002 (Y2) (3.4 customer satisfaction) }\end{array}$ & 2.733 & 0.006 \\
\hline $\begin{array}{c}\text { ISO 27001 (Y1) to ISO 10002 (Y2) (3.4 customer } \\
\text { satisfaction) }\end{array}$ & 6.960 & 0.000 \\
\hline $\begin{array}{c}\text { COBIT 5 (X1) (6.Customer-Oriented service value ) } \\
\text { to ISO 10002 (Y2) (3.4 customer satisfaction) } \\
\text { ITIL V3 (X2) (Service Operation 4.2 Incident }\end{array}$ & 3.260 & 0.001 \\
\hline $\begin{array}{c}\text { to ISO 10002 (Y2) (3.4 customer satisfaction) } \\
\quad\end{array}$ & & \\
\hline
\end{tabular}

Based on the above table, it is shown that the correlation of COBIT 5 (X1) (6.Customer-oriented service culture) to ISO 10002 (Y2) (3.4 customer satisfaction) with a T-Statistic value of 5.091> T-Table value of $1.969(\omega=0.05)$ and a P-Value of $0.000=0.05$.

There is therefore a strong and important link between COBIT 5 (X1) (6.Customer-oriented service culture) and ISO 10002 (Y2) (3.4 Customer satisfaction).

This means that the better COBIT 5 is applied, the better the customer's satisfaction. Corellation of ITIL V3 (X2) (Service Operation 4.2 Event Management) to ISO 10002 (Y2) 3.4 Customer satisfaction with a T-Statistic value of 2.648> T-Table value of $1.969(5-007=0.05)$ and a P-Value value of $0.008=0.05$. There is also a strong and important link between ITIL V3 (X2) (Service Operation 4.2 Incident Management) and ISO 10002 (Y1) (3.4 Customer Satisfaction). This means that the better ITIL V3 (X2) (Service operation 4.2 Incident management) is applied, the better Customer satisfaction is achieved.

Corellation of ISO 27001 (Y1) (A.16 Information Security Incident Management) to ISO 10002 (Y2) (3.4 Customer Satisfaction) with a T-Statistic value of 2.733> T-Table value of 1.969 ( $\amalg=0.05)$ and a $\mathrm{P}$-value of $0.006<_{\amalg}=0.05$. There is a positve and significant corellation of ISO 27001 and customer satisfaction. That means that the better ISO 27001, the better ISO 10002 (Y2) (3.4 customer satisfaction). corellation of COBIT 5 (X1) (6.Customer-oriented service culture) to ISO 27001 (Y1) (A.16 Information security incident management) with T-Statistic value of 6,960> T-Table value of $1,969(\omega=0,05)$ and P-Value of $0.000<\omega=0,05$.

There is a positve and significant corellation of of COBIT 5 (X1) (6.Customer-oriented service value) for ISO 27001 (Y2) (A.16 Information security incident management) This means that the better COBIT 5 (6.Customer-oriented service value) is applied, the better ISO 27001 (Y2) (A.16 Information security incident management is applied. The correlation of ITIL V3 (X2) (Service operation 4.2 incident management) on ISO 27001 (Y1) (A.16 Information security incident management) with a T-Statistic value of 3.260> a T-Table value of $1.969(\omega=0.05)$ and a $\mathrm{P}$-value of $0.001<\amalg=0.05$.

There is a positive and significant corellation of ITIL V3 (X2) (Service operation 4.2 incident management) and ISO 27001 (Y1) (A.16 Information security incident management). This means 
that the better ITIL V3 (X2) (Service opeartion 4.2 incident management) is applied, the better ISO 27001 is applied. The five hypotheses suggested in this analysis are therefore accepted. This is because each of the corellations shown has a T-Statistic value > a T-Table value of 1,969 $(\omega=0,05)$ and a P-Table value of $<0,05$. So that it can be claimed that exogenous variables on endogenous variables have a positive and meaningful correlation.

The largest effect is COBIT 5 (X2) (6.Customer-oriented service value) on ISO 27001 (Y1) (A.16 Information security incident management) with a T statistic of 6.960 and a $\mathrm{P}$ value of 0.000 . The structural model of the T-Statistic results is shown in Figure 3 below:

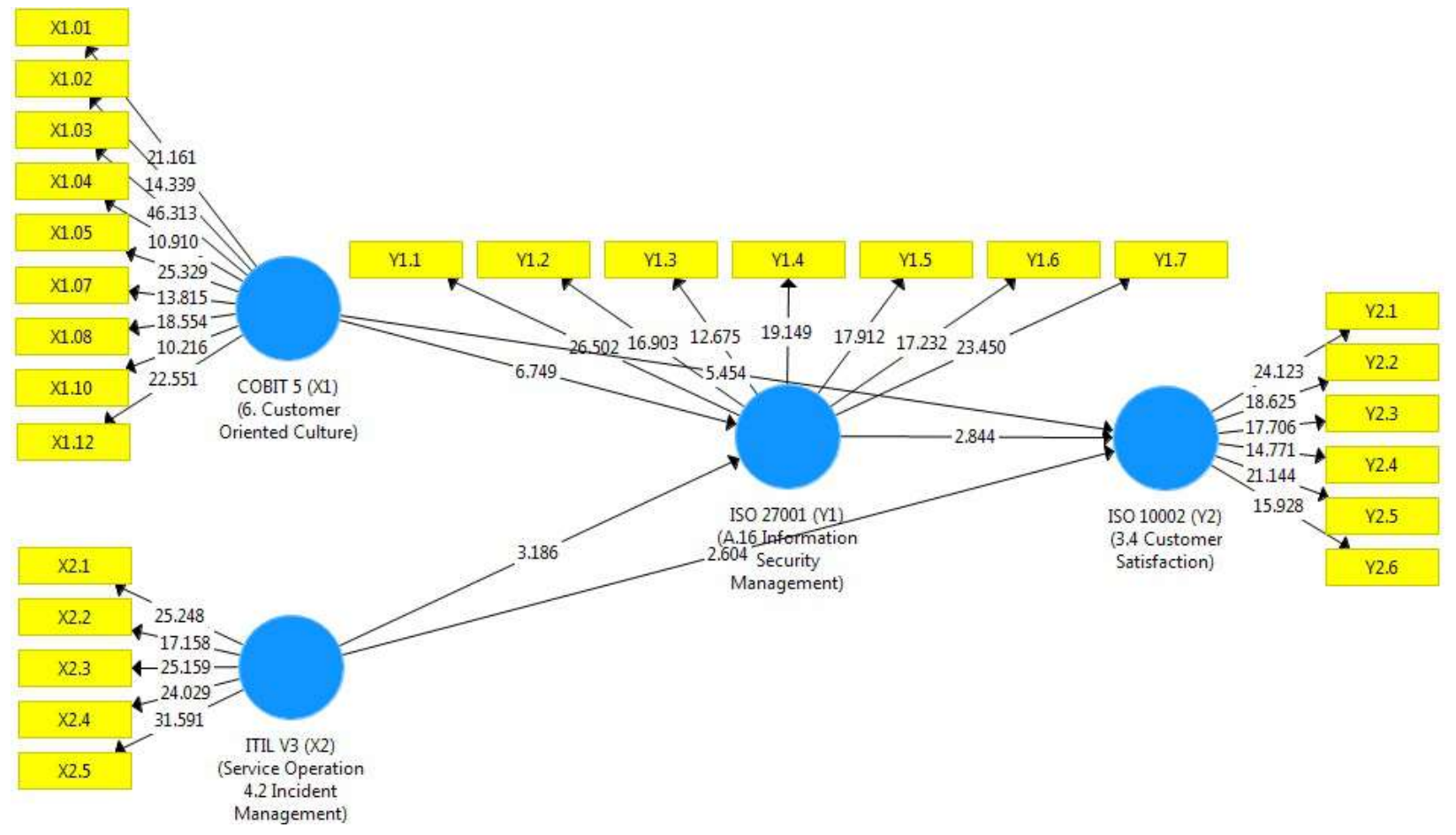

Figure 4. T-Statistic

The PLS model was evaluated by looking at the statistical significance (Q-square) of the constructive model.[10] The objective of the Q-square is to measure how well the observed value is generated by the model and also by estimating its parameters [19]. Measurement parameters are sure, if the results of the measurement suggest that the Q-square value is more than 0 (zero), then the model must be said to have the required predictive value. In the meantime, if the Q-square value is less than 0 (zero) it means that the model lacks predictive relevance. The Q-square equation results are as follows:

Table 11. T-Statistics and P-Values

\begin{tabular}{|l|l|}
\hline Latent Variable & Q Square \\
\hline $\begin{array}{l}\text { ISO 27001 (Y1) (A.16 } \\
\text { Information security incident } \\
\text { management) }\end{array}$ & 0.526 \\
\hline $\begin{array}{l}\text { ISO 10002 (Y2) (3.4 } \\
\text { customer satisfaction) }\end{array}$ & 0.578 \\
\hline
\end{tabular}

The table above shows that the Q-square value of ISO 27001 (Y1) is 0.526. The Q-square value of ISO 10002 (Y2) (3.4 customer satisfaction) is 0.578 . The results of the calculation show that the Q-square value is more than 0 (zero), so the model deserves to be said to have a good observation value or the model 
deserves to be said to have a relevant predictive value. The Model Goodness Test (Model Fit) uses the Standard Fit Index (NFI) which is a measure of the suitability of the model on a baseline or zero basis. The null model is typically a model that indicates that the variables used in the projected model are not intercorellations .[16]

Table 12. Model Fit

\begin{tabular}{|l|l|}
\hline Model Fit & $\begin{array}{l}\text { Nomed Fix Index } \\
\text { (NFI) }\end{array}$ \\
\hline $\begin{array}{l}\text { Saturated } \\
\text { Model }\end{array}$ & 0.418 \\
\hline
\end{tabular}

\section{Conclusion}

Based on the results of the above measurements, the value of the Nomed Fix Index (NFI) on the Saturated Model is 0.418.[9] The study model analyzed was 41.8\% in the fit or good category. [21] The results of the research findings suggest that there is a positive and significant correlation the application of COBIT 5 (X1) (6.Customer-oriented service culture), ITIL V3 (X2) (Service operation 4.2 incident management) and ISO 27001 (Y1) (A.16 Information security incident management) to ISO 10002 (Y2) (3.4 Customer satisfaction) [18] .This is consistent with the research results which show that ITIL and ISO/IEC 27001 systems can be used together as a basis for the development of a sound information security process. Both ITIL and ISO 27001 describe safety requirements for all aspects of infrastructure risk management services [13]. The system promotes management views that encourage and define services offered, manage user roles, manage tickets and generate management reports[9].

The value of government information technology (ITG) should use the latest method of ITIL V3 (Service operation 4.2 incident management) COBIT5 (X1) (6. Customer-oriented service culture) with ISO/IEC 27002 for effective use of ITG in the Moroccan Parliament.[17] ITIL V3, COBIT 5 with ISO/IEC 27002 as a set of organizations with legislative obligations, government control, public policy assessment, parliamentary diplomacy and the strengthening of parliamentary relations with constitutional institutions, good governance, advanced regional conferences, civil society and citizens[15]. Researchers would like to thank the leadership and the staff and customers of Quota Broadband Internet Company who have given permission to provide moral assistance in carrying out this report .[20]

\section{References}

[1] A. Jaschob and L. Tsintsifa, "IT-Grundschutz: Two-Tier risk assessment for a higher efficiency in IT security management. ISSE 2006- Secur Electro Bus Process”, Inform. Secur. Solut. Eur. Conf. Rome, Italy. pp: 95-101, 2006.

[2] A. Rezakhani, A. Hajebi, and N. Mohammadi, "Standardization of all information security management systems", International Journal of Computer Applications,(8), pp.4-8. 2011.

[3] B. Al Faruq, H. R. Herlianto, S. H. Simbolon, D. N. Utama, and A. Wibowo, "Integration of ITIL V3, ISO 20000 \& iso 27001:2013 forit services and security management system," Int. J. Adv. Trends Comput. Sci. Eng., vol. 9, no. 3, pp. 35143531, 2020, doi: 10.30534/ijatcse/2020/157932020.

[4] B. M. Practice, ITIL Service Operation. 2011.

[5] B. Niehaves and K. Ortbach, "The inner and the outer model in explanatory design theory: The case of designing electronic feedback systems," Eur. J. Inf. Syst., vol. 25, no. 4, pp. 303-316, 2016, doi: 10.1057/ejis.2016.3.

[6] "BS ISO 10002 : 2018 BSI Standards Publication Quality management — Customer satisfaction — Guidelines for complaints handling in organizations," 2018.

[7] D. Dragan and D. Topolšek, "Introduction to Structural Equation Modeling : Review , Methodology and Practical Applications," no. June, 2014.

[8] E. R. Larrocha, J. M. Minguet, G. Díaz, M. Castro and A.Vara, "Filling the gap of Information Security Management inside ITIL: proposals for postgraduate students", IEEE EDUCON Edu. Engg. pp: 907-912, 2010.

[9] F. Al-Hawari and H. Barham, "A machine learning based help desk system for IT service management, Journal of King Saud University - Computer and Information Sciences, pp. 1-17, 2019.

[10] Fornell and D. F. Larcker, "Evaluating structural equation models with unobservable variables and measurement error," Journal of marketing research, pp. 39-50, 1981.

[11] G. W. Cheung and R. B. Rensvold, "Structural Equation Modeling : A Evaluating Goodness-of- Fit Indexes for Testing Measurement Invariance,” no. July 2012, pp. 37-41, 2009. 
[12] I. Ghozali, Structural Equation Modeling - Alternative Method with Partial Least Squares (PLS). Semarang: Universitas Diponegoro, p. 39, 2014.

[13] ISACA, “cobit 2019 5: A business framework for the governance and management of enterprise IT”, Isaca, 2012.

[14] J. F. Hair, M. Sarstedt, C. M. Ringle, and J. A. Mena, "An assessment of the use of partial least squares structural equation modeling in marketing research," pp. 414-433, 2012, doi: 10.1007/s11747-011-0261-6.

[15] J. Henseler and W. W. Chin, "Structural Equation Modeling : A A Comparison of Approaches for the Analysis of Interaction Effects Between Latent Variables Using Partial Least Squares Path Modeling," no. August 2013, pp. 37-41, doi: 10.1080/10705510903439003.

[16] K. V. Warre, "Security controls in service management. SANS Institute reading room", 2010. from http://www.sans.org/search/results.

[17] M. Motii, and A. Semma, "Towards a new approach to pooling COBIT 5 and ITIL V3 with ISO/IEC 27002 for better use of ITG in the Moroccan parliament”, IJCSI International Journal of Computer Science Issues, Volume 14, Issue 3, pp. 49-58, May 2017.

[18] K.L. Thomson, and R.V. Solms , “Information Security governance: COBIT or ISO 17799 or both?”, J. Comput. Secur. 24, pp. 99-104, February 2005.

[19] Riadi, E., 2018. Statistik SEM structural equation modeling dengan Lisrel. Yogyakarta: CV Andi Offset.

[20] R. Sheikhpour, and N. Modiri, "A best practice approach for integration of ITIL and ISO/IEC 27001 services for information security management", Indian journal of science and technology, 5(2), pp.2170-2176, 2012.

[21] S. Sahibudin, M. Sharifi, and M. Ayat, "Combining ITIL, COBIT and ISO/IEC 27002 in order to design a comprehensive IT framework in organizations," Proc. - 2nd Asia Int. Conf. Model. Simulation, AMS 2008, pp. 749-753, 2008, doi: 10.1109/AMS.2008.145.

[22] T. Pereira, and H. Santos, "A security audit framework to manage Information system security. In International Conference on Global Security, Safety, and Sustainability," Springer, Berlin, Heidelberg, pp. 9-18, September 2010.

[23] S. Yamin dan H. Kurniawan, The New Generation Processes Research Data with Partial Least Square Path Modeling. Jakarta: Salemba Empat, p. 54, 2011.

[24] W. Boehmer, "Appraisal of the corellationiveness and efficiency of an Information Security Management System based on ISO 27001". Proc. Second Int. Conf. Emerging Security Information, Sys. \& Technolos. Yogyakarta: Ekonisia, 2005.gies. pp: 224-231, 2008.

[25] V. Grover, M. J. Cheon, and J. T. C. Teng, "of Service Quality and The Effect of on the Outsourcing Partnership Functions Information Systems," vol. 12, no. 4, pp. 89-116, 2015.

[26] V. Rangan, "INTERNATIONAL STANDARD ISO / IEC Information technology — Security techniques — Information security management systems - Requirements," vol. 2013, 2013. 